\title{
DESAIN DAN VALIDASI SISTEM OTOMASI FEEDER MESIN RUN-OUT VELG STEEL UNTUK MOBIL KATEGORI I-IV MENGGUNAKAN METODE VDI 2221
}

\author{
Yunus Yakub ${ }^{1)}$, Erizal ${ }^{2)}$ dan Adhithya Yudo Yulianto ${ }^{3)}$ \\ Program Studi Teknik Mesin, Institut Sains dan Teknologi Nasional \\ Jl. Moh. Kahfi II, Jagakarsa, Jakarta 12640
}

\begin{abstract}
Automation is one of method in production process in manufacturing sector. Automation changes work system of man-power become to automatically system as the result of combination beetween mechanical and electrical. Automation implemented at material transfer process in production process of steel wheel for car with category I-IV at PT. X. Material transfer of wheel has begin from welding process and going to Run-Out machine where dimension checking take place. Automatic feeder have function as a equipment to helps steel wheel transfer to Run-Out machine. With design method of VDI 2221, have result of best automatic feeder machine design concept from technical aspect and economic from some alternative concepts. At the design, feeder use pneumatic as actuator and logic of PLC program that triggered by sensor. Feeder machine produces optimalization of working time during production process because of consistency of production process. Beside of that, produces cost efficiency from investation because expenditure for man-power can be allocated to other position in production line.
\end{abstract}

Keywords : automation, pneumatic, material transfer, VDI 2221.

\section{PENDAHULUAN}

Proses penanganan material merupakan hal penting dalam proses produksi.Penulisan skripsi ini juga di latar belakangi adanya sebuah ide perbaikan dalam proses produksi pada transfer material velg di lini Assembly PT. X. Yaitu proses transfer material berupa velg yang dipindahkan dari gravity konveyor menuju mesin Run-Out otomatis oleh Feeder. Prinsip kerjanya adalah merubah arah gerak velg dari gravity conveyor menuju mesin Run-Out. Kondisi sebelum dilakukan ide perbaikan adalah pada Feeder masih dioperasikan oleh seorang Man Power, yang fungsi kerjanya mengatur datangnya velg yang datang menuju mesin RunOut. Namun, terdapat permasalahan yang terjadi pada saat proses produksi berlangsung. Yaitu adanya penumpukan velg pada konveyor dari welding station yang menuju ke mesin RunOut.

Untuk mengetahui lebih dalam dan detail permasalahan yang ada, perlu dilakukan analisa akar masalah dari kejadian penumpukan velg di area menuju Mesin Run-Out. Hal ini bertujuan, dapat menentukan solusi terbaik dari permasalahan yang dihadapi.
Table 1. Solusi Akar Masalah

\begin{tabular}{|l|l|l|l|l|}
\hline No. & \multicolumn{1}{|c|}{ Akar Masalah } & \multicolumn{1}{|c|}{ Rekomendasi } & $\begin{array}{c}\text { Tingkat } \\
\text { Keberhasilan }\end{array}$ & Implikasi Biaya \\
\hline 1 & $\begin{array}{l}\text { Perbedaan } \\
\text { waktu kerja } \\
\text { antara proses } \\
\text { welding dan } \\
\text { Run-Out }\end{array}$ & $\begin{array}{l}\text { Penyeragaman waktu kerja } \\
\text { antara kedua proses. } \\
\text { - Memperlambat proses } \\
\text { welding }\end{array}$ & Rendah & Rendah \\
\hline 2 & $\begin{array}{l}\text { Jumlah input } \\
\text { dan output yang } \\
\text { tidak sebanding }\end{array}$ & $\begin{array}{l}\text { - Penyeragaman jumlah input } \\
\text { dan output mesin } \\
\text { - Penambahan jumlah mesin } \\
\text { Run-Out }\end{array}$ & Tinggi & Tinggi \\
\hline 3 & $\begin{array}{l}\text { Layout mesin } \\
\text { yang kurang } \\
\text { mendukung } \\
\text { proses produksi }\end{array}$ & $\begin{array}{l}\text { Penambahan panjang jalur } \\
\text { konveyor menuju Mesin } \\
\text { Run-Out } \\
\text { - Penurunan sudut } \\
\text { kemiringan konveyor }\end{array}$ & Tinggi & Tinggi \\
\hline 4 & $\begin{array}{l}\text { Wembuatan sistem otomasi } \\
\text { saat produksi } \\
\text { masih } \\
\text { berlangsung }\end{array}$ & $\begin{array}{l}\text { - Pembuatan sistem buffer } \\
\text { untuk velg menuju Mesin } \\
\text { Run-Out }\end{array}$ & Tinggi & Rendah \\
\hline
\end{tabular}

Dari tabel solusi akar masalah, didapatkan hasil bahwa solusi yang terbaik adalah dengan membuatkan sistem otomasi pada area yang menuju ke mesin Run-Out dan dilengkapi juga dengan sistem buffer untuk mengatasi input dari Mesin Welding yang jumlahnya lebih banyak daripada mesin Run-Out. Kriteria pemilihan ini didasarkan pada tingkat keberhasilan yang dinilai tinggi dan biaya yang digunakan rendah. 
Dalam melakukan analisa diperlukan ruang lingkup dan pembatasan permasalahan agar pembahasan yang akan dilakukan dan penarikan kesimpulan lebih terarah. Beberapa batasan permasalahan yang diambil adalah sebagai berikut:

1. Sistem mekanika feeder otomatis yang mampu mengakomodasi velg untuk rentang ukuran 12 inch hingga 17 inch.

2. Memvalidasi hasil penerapan sistem otomasi pada proses produksi untuk produksi velg dengan rentang ukuran 12 inch hingga 17 inch.

Maksud dan tujuan dari pembuatan Feeder Mesin Run-Out Velg Steel Untuk Mobil Kategori I-IV di PT. X ini adalah :

1. Sebagai penerapan sistem otomasi di dalam dunia industri khususnya untuk proses penanganan perpindahan material berupa velg mobil dari Welding Station menuju ke Proses pengukuran dimensi akhir pada Mesin Run-Out.

2. Sebagai penerapan sistem otomasi pada industri yang bertujuan efisiensi dalam segi waktu kerja dan peningkatan jumlah produksi.

\section{TINJAUAN PUSTAKA \\ Otomasi Industri}

Otomasi industri adalah seperangkat teknologi yang memiliki dampak pada operasional mesin industri dan sistemnya tanpa ada intervensi manusia secara signifikan dan tercapainya kehandalan yang jauh lebih baik dibandingkan operasi secara manual.

\section{Pneumatik}

Pneumatik dalam pelaksanaan teknik udara mampat dalam industri (khususnya dalam teknik mesin) merupakan ilmu pengetahuan dari semua proses mekanis di mana udara memindahkan suatu gaya atau suatu gerakan. Dalam pengertian yang lebih sempit pneumatik dapat diartikan sebagai teknik udara mampat (compressed air technology). Sedangkan dalam pengertian teknik pneumatik meliputi : alat-alat penggerakan, pengukuran, pengaturan, pengendalian, penghubungan dan perentangan yang meminjam gaya dan penggeraknya dari udara mampat.

Susunan sistem Pneumatik merupakan suatu rangkaian yang bila dijalankan maka akan melakukan kerja.Adapun susunan sistem Pneumatik terdiri atas:

1. Catu Daya (Energy Supply)

Yang dimaksud catu daya ini adalah pembangkit udara bertekanan (compressor). Catu daya merupakan tempat tersimpannya energi yang siap melakukan tekanan kerja pada suatu rangkaian jika kran penutup dibuka.

2. Elemen Masukan (Sensors)

Elemen masukan atau sensor disini merupakan suatu alat yang digunakan untuk memulai jalan kerja pada setiap rangkaian.

3. Elemen Pengolah (Processors)

Elemen pengolah merupakan alat yang melakukan pengolahan aliran sebelum aliran sebelum aliran dijalankan ke elemen control.

4. Elemen Pengontrol (Final Control Element)

Elemen pengontrol merupakan terdiri dari alat atau katup yang mengontrol gerakan kerja aliran udara sesuai dengan sinyal-sinyal yang diberikan.

5. Elemen kerja

Elemen kerja di sini berupa silinder yang dapat menggerakkan piston sesuai dengan aliran udara yang diberikan.

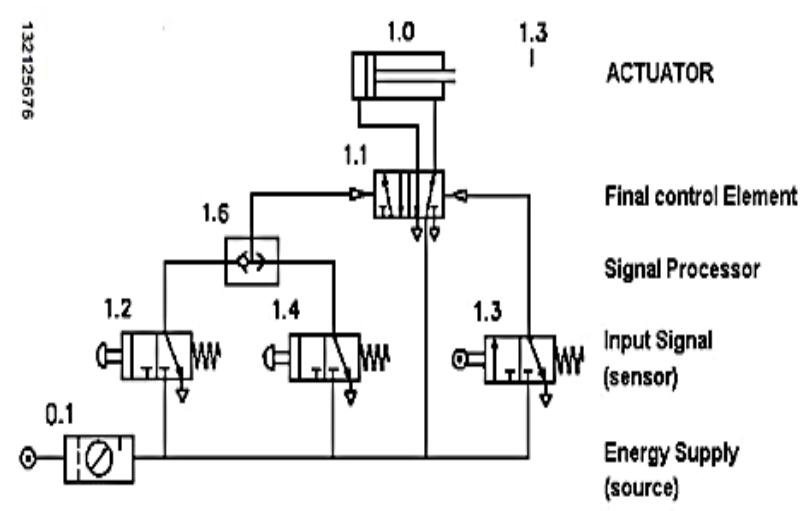

Gambar 1: Susunan Sistem Pneumatik

\section{End Effector}

Piranti yang terpasang pada lengan sistem mekanis untuk melaksanakan fungsi-fungsi tertentu. Jenisnya antara lain:

1. Gripper (pencengkram) : piranti untuk memegang dan mencengkram obyek, misalnya : tangan mekanik, piranti pengait, magnet atau penghisap.

2. Tool (peralatan) : Piranti yang digunakan untuk melakukan operasi pada suatu obyek. Misalnya : bor, penyemprot cat, gerinda, alat las dan lain-lain. 


\section{Tahap Perancangan}

Metode VDI 2221 memiliki langkah kerja dan hasil kerja yang dapat dibagi menjadi empat tahap pengerjaan yaitu :

1. Tahap I : Mengklasifikasi tugas

2. Tahap II : Perencanaan konsep

3. Tahap III : Perencanaan bentuk

4. Tahap IV : Perencanaan secara rinci

Tahapan dalam metode VDI 2221 ditunjukkan pada gambar 2 berikut :
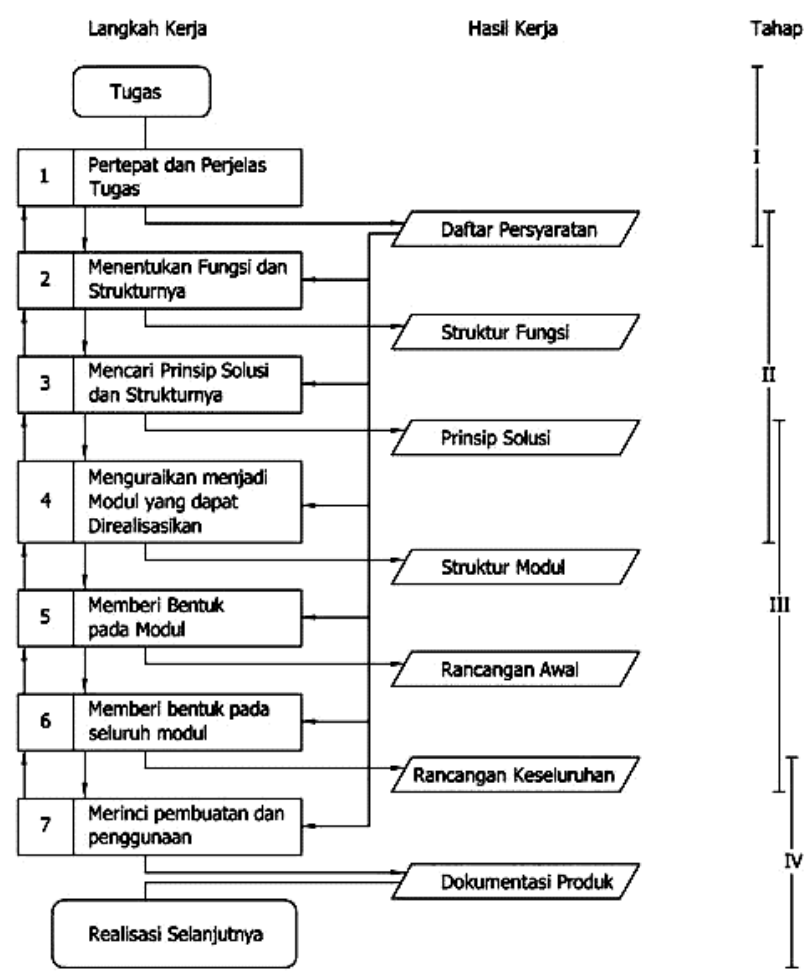

Gambar 2. Skema Langkah Kerja VDI 2221

\section{METODE PERANCANGAN \\ Metode Perancangan}

Metode Perancangan merupakan proses berpikir sistematis terhadap suatu sistem, komponen atau produk bahkan proses untuk mencapai sesuatu yang diharapkan seperti mendapatkan atau mengumpulkan data yang diperlukan, kemudian menyajikan, mengolah dan menganalisa data tersebut. Metodologi perancangan dapat juga dikatakan sebagai proses pengambilan keputusan. Untuk tahapan perancangan dapat dilihat pada diagram alir seperti yang ditunjukkan pada gambar 3 berikut :

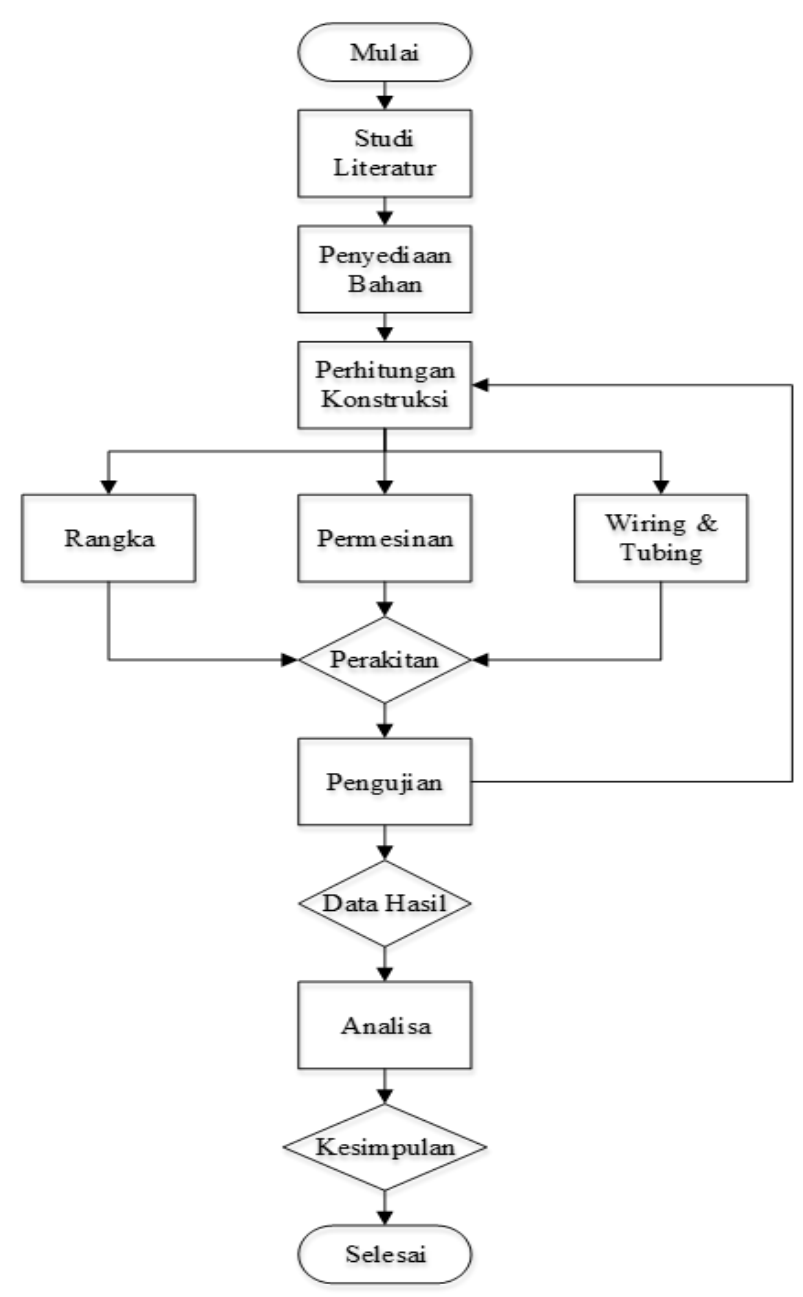

Gambar 3. Diagram Alir Proses Perancangan

\section{Tahapan Sistem Perancangan}

Untuk mendapatkan suatu rancangan yang optimal diperlukan suatu langkah-langkah perancangan yang tersusun secara sistematis. Tahapan perancangan yang biasa digunakan adalah sebagai berikut :

1. Merencana

2. Pembuatan Konsep

3. Merancang

4. Penyelesaian

\section{Spesifikasi Feeder Otomatis}

Untuk mendapatkan data sebuah rancangan maka perlu disusun dasar-dasar spesifikasi yang bersifat menunjang apa yang akan didesain. Ditunjukkan pada tabel 3.1 berikut : 
Tabel 2. Spesifikasi Feeder Otomatis

\begin{tabular}{|c|c|c|c|}
\hline \multicolumn{2}{|c|}{$\begin{array}{l}\text { DESAIN FEEDER } \\
\text { OTOMATIS }\end{array}$} & \multirow{2}{*}{$\begin{array}{l}\text { SPESIFIKASI DAN SUB FUNGSI } \\
\text { KEHENDAK }\end{array}$} & \multirow{2}{*}{\begin{tabular}{|c|c|}
$\begin{array}{c}\text { DENTIFIKASI } \\
\text { KLASIFIKASI } \\
\text { Halaman 1/1 }\end{array}$ \\
$\begin{array}{c}\text { PENANGGUNG } \\
\text { JAWAB }\end{array}$ \\
\end{tabular}} \\
\hline PERUBAHAN & D/W & & \\
\hline & $\begin{array}{l}D \\
D \\
W\end{array}$ & 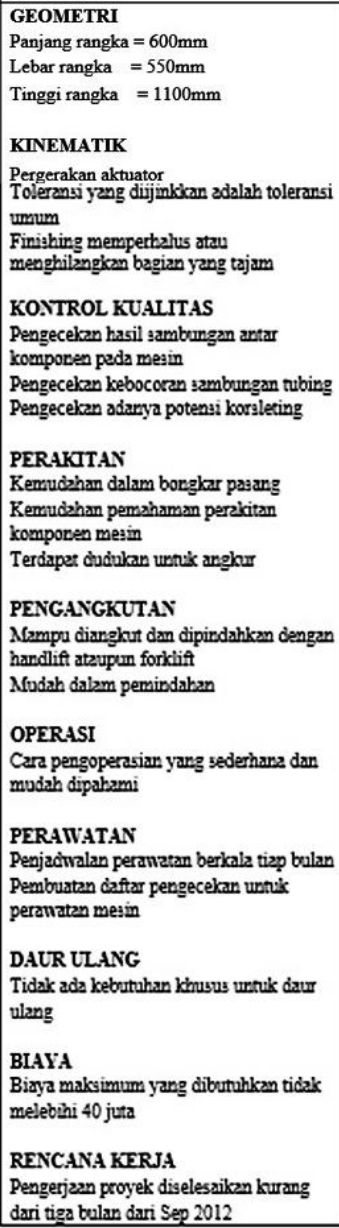 & Bahuddin \\
\hline & $\begin{array}{l}D \\
D \\
W\end{array}$ & 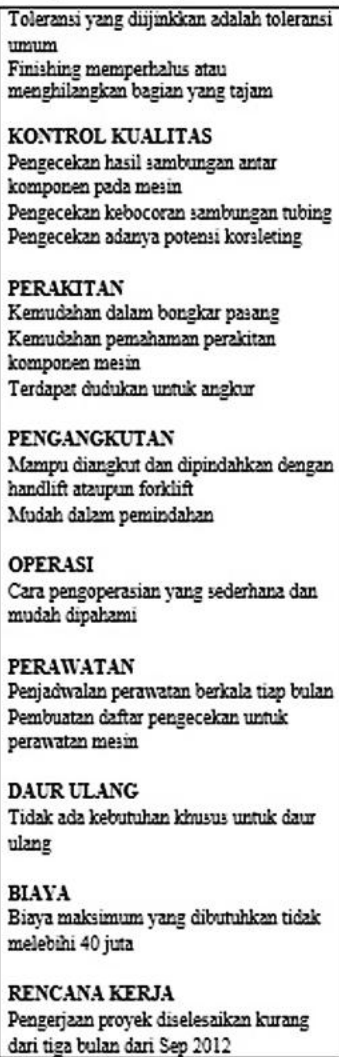 & $\begin{array}{l}\text { Banuddin } \\
\text { Bahuddin }\end{array}$ \\
\hline
\end{tabular}

\section{Fungsi Keseluruhan}

Fungsi keseluruhan ini berkaitan dengan sistem yang bekerja pada alat atau mesin yang akan dibuat. Untuk Feeder Otomatis yang akan dibuat, memiliki fungsi keseluruhan yaitu menerima material velg yang berasal dari Welding Station menuju Mesin Run-Out dan memiliki sistem buffer untuk mengakomodasi jumlah velg yang akan diproses di Mesin RunOut. Dari penjelasan diatas, secara lebih detail, fungsi keseluruhan yang digunakan pada Feeder Otomastis, sebagai berikut:

a. Sistem Penahan, merupakan bagian dari sistem yang berfungsi sebagai buffer atau menahan velg yang datang saat ada velg lain yang sedang diproses di Mesin Run-Out.

b. Sistem Pengangkat, merupakan bagian dari sistem yang berfungsi sebagai menaikkan level ketinggian velg dari gravity konveyor agar mengurangi gesekan saat velg ditransfer ke Mesin Run-Out.

c. Sistem Pendorong, merupakan bagian dari sistem yang berfungsi sebagai pemindah material velg dari meja feeder untuk menuju ke mesin Run-Out.

\section{Fungsi Bagian}

Agar dapat memenuhi konsep yang telah dibuat dan direncanakan diatas, maka mesin feeder otomatis ini harus memiliki beberapa fungsi bagian, antara lain:

a. Mekanisme penggerak, berfungsi sebagai pemberi pergerakan transfer material dari input menuju output yang diinginkan dengan aktuator.

b. Mekanisme penjepit atau gripper, berfungsi sebagai komponen penjepit material yang ditransfer agar feeder otomatis dapat beroperasi sesuai dengan gerakan dari mesin Run-Out.

c. Mekanisme transfer material, berfungsi sebagai perangkat yang dapat memindahkan material velg menuju ke proses berikutnya.

d. Konstruksi rangka, berfungsi sebagai rangka yang menopang komponen-komponen yang dibebankan agar dapat tersusun dan bekerja sesuai dengan fungsinya. 


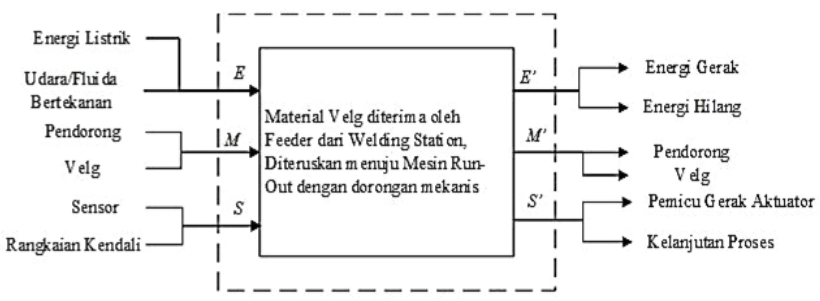

Gambar 4. Fungsi Bagian Mesin Feeder Otomatis

Dari alternatif bagian-bagian utama dari mesin yang sudah dibuat, langkah selanjutnya adalah membuat gabungan dari alternatif tersebut sehingga diharapkan dapat mencapai konsep mesin Feeder Otomatis yang efektif. Pada tabel 3 berikut ditunjukkan alternatif gabungan dari mesin Feeder Otomatis :

Tabel 3. Alternatif Fungsi Mekanisme Feeder

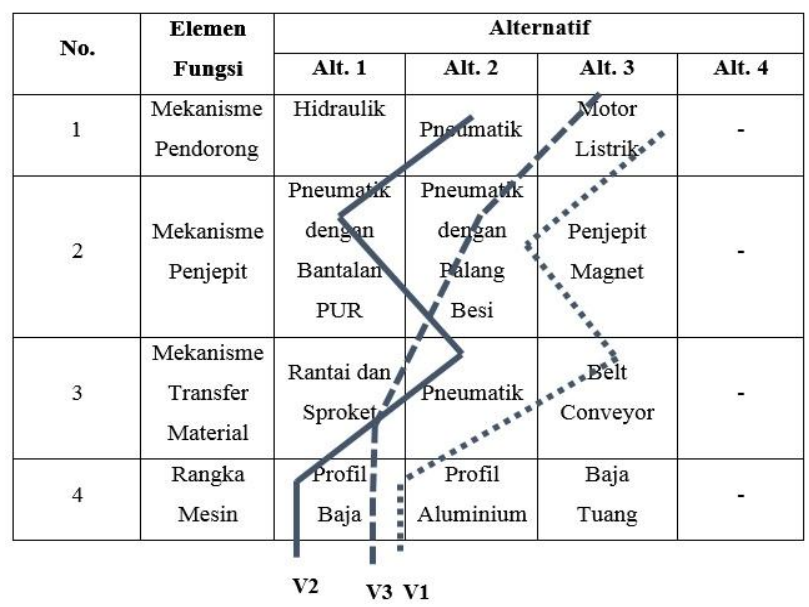

Dari konsep varian yang telah didapat, selanjutnya dievaluasi terhadap kriteria teknik. Dalam pengevaluasian ini ditinjau dari daftar (spesifikasi) yang telah dibuat sebelumnya, khususnya pada syarat mutlak. Pemenuhan untuk syarat mutlak dalam hal ini, belum mencakup keseluruhan syarat, tetapi hanya dalam perkiraan atau berdasarkan informasi yang telah didapat. Jadi pengevaluasian ini yang sebenarnya atau sesungguhnya dicari adalah konsep varian yang paling memberikan harapan yaitu dapat melaksanakan fungsi keseluruhan dalam proses transfer produk velg, mudahnya pengoperasian alat (dapat dilakukan oleh semua operator pabrik), perbaikan apabila ada kerusakan dapat dideteksi secara cepat dan akurat oleh bagian perawatan, biaya perawatan yang murah, suku cadang yang dapat dengan mudah dijumpai di pasaran. Dari konsep varian yang telah didapat pada perancangan Feeder otomatis untuk velg ini dapat dievaluasikan sebagaimana ditunjukkan pada tabel 4:
Tabel 4. Evaluasi Konsep Desain

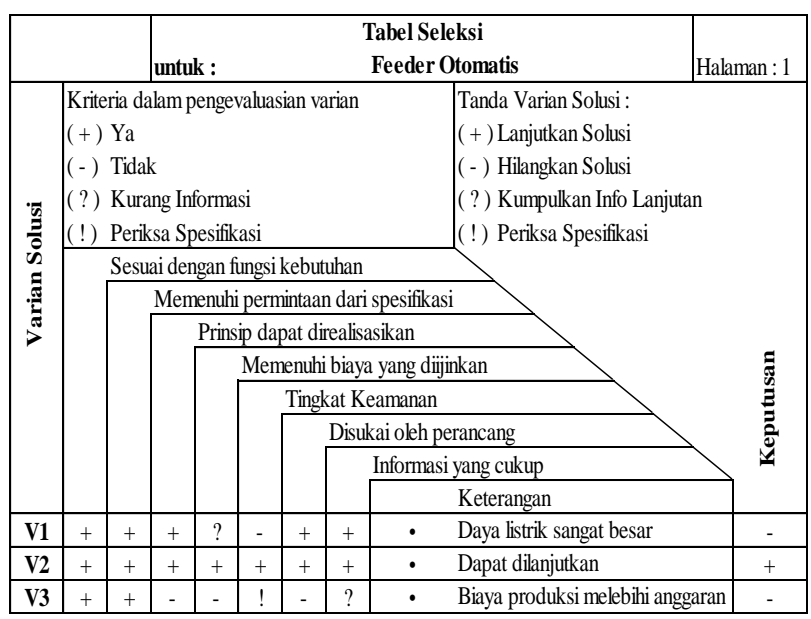

Setelah mengevaluasi konsep desain dari varian yang ada, di dapatkan varian yang dapat di lanjutkan untuk mendapatkan solusi yang terbaik untuk konsep perancangan Feeder Otomatis. Dari informasi yang ada pada kriteria evaluasi dikembangkan kembali menjadi klasifikasi yang detail atas parameter yang ada. Dari parameter yang ada, dilakukan pembobotan dan klasifikasi dalam bentuk pohon obyektif.Tahap berikutnya adalah membuat tabel evaluasi dengan nilai mengacu pada pohon obyektif yang berisi parameter-parameter di dalamnya.

Meskipun sudah didapatkan nilai terbaik untuk varian konsepnya, proses evaluasi untuk mengetahui titik lemah dari konsep juga tetap harus dilakukan. Hal ini dimaksudkan sebagai pemeriksaan evaluasi terhadap parameter yang nilainya di bawah rata-rata. Untuk analisa titik lemah ini, dilakukan terhadap dua varian yaitu varian terbaik pertama dan kedua sebagai pembandingnya. Diagram analisa titik lemah varian untuk mesin feeder otomatis seperti pada gambar 5:

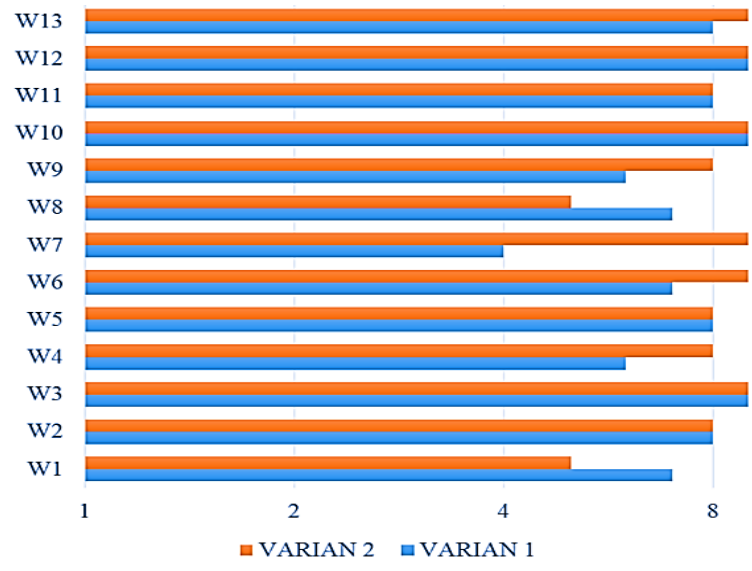

Gambar 5. Riwayat Nilai untuk Identifikasi Titik Lemah Varian 


\section{Tahapan Pembuatan Konstruksi}

Pada tahap akhir ini dijelaskan mengenai susunan dari Feeder Otomatis untuk velg yang dirancang dengan hasilnya adalah berupa sebuah produk mesin. Untuk mewujudkan rancangan menjadi produk mesin dilakukan dengan beberapa keperluan penting seperti berikut :

1. Persiapkan material yang digunakan

2. Persiapkan peralatan yang digunakan

3. Diagram Pneumatik Elektrik

\section{PERHITUNGAN RANCANG BANGUN Perancangan Sistem Mekanik}

Dalam perancangan Feeder Otomatis ini, sudah ditetapkan fungsi keseluruhan dari sistem mekanikanya. Secara fungsinya, terdapat tiga fungsi yaitu mekanisme penahan, mekanisme pengangkat dan mekanisme pendorong. Semua mekanisme tersebut dikaji dalam beberapa metode, diantaranya Analisa Derajat Kebebasan (Degree of Freedom), Analisa Free Body Diagram, dan penentuan secara dimensional sistem mekanikanya.

\section{Analisis Gaya Velg di Konveyor}

Pada bagian mekanisme penahan ini, memiliki fungsi untuk menahan material velg untuk masuk ke meja feeder, jika ada material velg di area meja feeder. Velg yang datang berasal dari proses welding yang turun menuju ke mesin Run-Out melewati roll konveyor dengan kemiringan sebesar $10^{\circ}$.

Tabel 5. Analisa Gaya Velg di Konveyor

\begin{tabular}{|c|c|}
\hline Analisa DOF & Diagram Benda Bebas \\
\hline
\end{tabular}

Maka perhitungannya sebagai berikut :

$$
\begin{aligned}
& F_{N}=\mu \cdot F_{g} \cdot \cos \theta \\
& F_{N}=0,78 \cdot(15 \cdot 9,81) N \cdot \cos 10^{\circ} \\
& F_{N}=0,78 \cdot 147 N \cdot 0,985 \\
& F_{N}=113 N
\end{aligned}
$$

Dari kalkulasi didapatkan kesimpulan bahwa gaya normal yang dihasilkan saat sebuah velg berjalan turun diatas konveyor memiliki nilai $113 \mathrm{~N}$.

\section{Perancangan Mekanisme Penahan}

Setelah mengetahui besar beban yang berasal dari velg yang turun dari konveyor, maka tahap selanjutnya adalah menentukan mekanisme penahan yang digunakan.

Tabel 6. Analisa Mekanisme Penahan

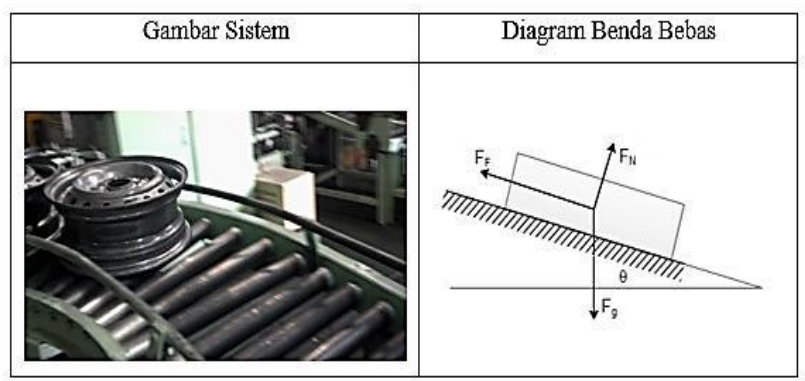

Dalam analisa mekanisme penahan, terlebih dahulu dihitung jumlah derajat kebebasannya. Untuk derajat kebebasan yang terjadi, sebagai berikut:

$$
\begin{aligned}
& F=3(n-1)-2 l-h \\
& F=3(5-1)-2 \times 5-1 \times 0 \\
& F=2 \\
& \mathrm{n}=5(1,2,3,4,5) ; 1=5(\mathrm{~A}, \mathrm{~B}, \mathrm{C}, \mathrm{E}, \mathrm{F}) ; \mathrm{h}=0
\end{aligned}
$$

Dari analisa derajat kebebasan diatas, dihasilkan bahawa mekanisme penahan memiliki dua derajat kebebasan, yaitu pergerakan titik 1 dan 5 secara rotasi di sumbu Y ditandai dengan terbuka dan tertutupnya penahan.

\section{Perancangan Mekanisme Pengangkat}

Pada bagian mekanisme pengangkat ini, memiliki fungsi untuk mengangkat material velg yang ada diatas meja feeder, jika ada material velg di area meja feeder maka akan dideteksi oleh photosensor.

Tabel 7. Analisa Mekanisme Pengangkat

\begin{tabular}{|c|c|}
\hline \multicolumn{3}{|c|}{ Analisa DOF } & Diagram Benda Bebas \\
\hline & \\
\hline
\end{tabular}


Dalam analisis mekanisme pengangkat, terlebih dahulu dihitung jumlah derajat kebebasannya. Untuk derajat kebebasan yang terjadi, sebagai berikut:

$$
\begin{aligned}
& F=3(n-1)-2 l-h \\
& F=3(3-1)-2 \times 3-1 \times 0 \\
& F=1 \\
& \mathrm{n}=3(1,2,3) ; 1=3(\mathrm{~B}, \mathrm{C}, \mathrm{D}) ; \mathrm{h}=0
\end{aligned}
$$

Dari analisis derajat kebebasan diatas, dihasilkan bahawa mekanisme penangkat memiliki satu derajat kebebasan, yaitu pergerakan secara vertikal sesuai dengan gerakan yang dihasilkan pneumatik.

Selanjutnya menghitung usaha yang dibutuhkan untuk mengangkat material velg terangkat agar tidak satu permukaan dengan meja feeder. Keterangan pada sistem adalah sebagai berikut:

Berat velg maksimum : $15 \mathrm{~kg}$

Keyinggian $\quad: 0,05 \mathrm{~m}$

Nilai gravitasi $\quad: 9,81 \mathrm{~kg} / \mathrm{m}^{2}$

Maka perhitungannya sebagai berikut :

$$
\begin{aligned}
& W=F_{g} \times \Delta h \times \cos \theta \\
& W=(15 \times 9,81) N \times 0,05 m \times \cos 0^{\circ} \\
& W=147 N \times 0,05 m \times 1 \\
& W=7,35 \mathrm{~J}
\end{aligned}
$$

\section{Perancangan Mekanisme Pendorong}

Pada bagian mekanisme pendorong ini, memiliki fungsi untuk mendorong material velg yang ada diatas meja feeder untuk menuju ke Mesin Run-Out. Sebelumnya, material velg diangkat dahulu agar tidak satu permukaan dengan roll konveyor untuk mengurangi gesekan.

Tabel 8. Analisa Mekanisme Pendorong

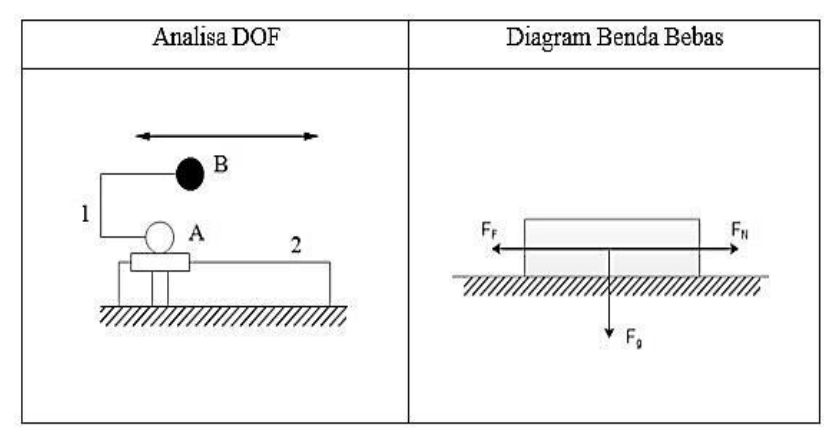

Dalam analisa mekanisme pendorong, terlebih dahulu dihitung jumlah derajat kebebasannya. Untuk derajat kebebasan yang terjadi, sebagai berikut:

$$
\begin{aligned}
& F=3(n-1)-2 l-h \\
& F=3(2-1)-2 \times 1-1 \times 0
\end{aligned}
$$

$$
\begin{aligned}
& F=1 \\
& \mathrm{n}=3(1,2) ; 1=1(\mathrm{~A}) ; \mathrm{h}=0
\end{aligned}
$$

Dari analisis derajat kebebasan diatas, dihasilkan bahawa mekanisme pendorong memiliki satu derajat kebebasan, yaitu pergerakan secara horizontal sesuai dengan gerakan yang dihasilkan pneumatik tipe rodless cylinder.

Selanjutnya menghitung usaha yang dibutuhkan untuk mendorong material velg diatas meja feeder. Keterangan pada sistem adalah sebagai berikut:
Berat velg $: 15 \mathrm{~kg}$

Koefisien gesek : 0,78 (Steel ke Steel)

Jarak pindah : $0,6 \mathrm{~m}$

Nilai gravitasi $: 9,81 \mathrm{~kg} / \mathrm{m} 2$

Maka perhitungannya sebagai berikut :

$$
\begin{aligned}
& W=F_{N} x \Delta r \times \cos \theta \\
& W=(15 \times 9,81 \times 0,78) N \times 0,6 m \times \cos 0^{\circ} \\
& W=115 N \times 0,6 m \times 1 \\
& W=69 J
\end{aligned}
$$

\section{Perancangan Sistem Pneumatik}

Penerapan pneumatik sebagai media aktuator untuk transfer material sudah banyak diterapkan di berbagai industri yang menggunakan sistem otomasi dalam produksinya. Sehingga, untuk mesin Feeder Otomatis ini juga menggunakan pneumatik sebgai media aktuatornya. Dalam hal ini, pneumatik digunakan dalam fungsi sebagai media buffer material produk, mengangkat material, dan mendorong material menuju proses berikutnya. Dengan berbagai fungsi pneumatik dalam mesin Feeder Otomatis ini, maka perlu dilakukan perhitungan terkait dengan gaya-gaya yang bekerja pada sebuah sistem pneumatik ini.

\section{Perencanaan Silinder Pneumatik}

Menentukan ukuran silinder pneumatik yang akan digunakan dalam sistem adalah langkah pertama dalam menggunakan pneumatik pada sebuah mesin. Hal ini penting karena dengan mengetahui ukuran silinder yang digunakan, akan diketahui kapasitas tenaga yang dihasilkan oleh silinder tersebut terhadap beban yang diterima. Namun, sebelum dilakukan kalkulasi perlu dilakukan klasifikasi silinder pneumatik yang digunakan. Karena dalam penggunaannya digunakan empat buah 
silinder pneumatik dengan tiga fungsi dan model yang berbeda.

Pneumatik yang digunakan untuk penahan adalah dengan spesifikasi sebagai berikut:

Diameter rod : $16 \mathrm{~mm}$

Diameter silinder : $40 \mathrm{~mm}$

Panjang langkah : $75 \mathrm{~mm}$

Tipe pneumatik : Double acting (SMC CA2D40-75)

Berat velg maksimum: $15 \mathrm{~kg} \approx 147 \mathrm{~N}$

Maka perhitungannya sebagai berikut :

$$
\begin{aligned}
& F=p \cdot \pi \cdot\left(D^{2}-d^{2}\right) / 4 \\
& F=4 \cdot 3,14 \cdot\left(40^{2}-16^{2}\right) / 4 \\
& F=422[N]
\end{aligned}
$$

Dari kalkulasi didapatkan kesimpulan bahwa pneumatik yang digunakan mampu dengan mudah menahan beban yang diterima yaitu memiliki nilai $422 \mathrm{~N}$, yang artinya memiliki angka aman sebesar 2,8 kali dari beban aktual yaitu $147 \mathrm{~N}$.

Pneumatik yang digunakan adalah dengan spesifikasi sebagai berikut:

Diameter rod : $16 \mathrm{~mm}$

Diameter silinder : 40mm

Panjang langkah : 50mm

Tipe pneumatik : Double acting (SMC CA2G40-50)

Berat maksimum : $25 \mathrm{~kg} \approx 245 \mathrm{~N}$

Maka perhitungannya sebagai berikut :

$$
\begin{aligned}
& F=p \cdot \pi \cdot\left(D^{2}-d^{2}\right) / 4 \\
& F=4 \cdot 3,14 \cdot\left(40^{2}-16^{2}\right) / 4 \\
& F=422[N]
\end{aligned}
$$

Dari kalkulasi didapatkan kesimpulan bahwa pneumatik yang digunakan mampu dengan mudah menahan beban yang diterima yaitu memiliki nilai $422 \mathrm{~N}$, yang artinya memiliki angka aman sebesar 1,7 kali dari beban aktual yaitu $245 \mathrm{~N}$.

Pneumatik yang digunakan adalah dengan spesifikasi sebagai berikut:

Diameter rod : $32 \mathrm{~mm}$

Diameter silinder : $50 \mathrm{~mm}$

Panjang langkah : 500mm

Tipe pneumatik : Single acting (MEDAN PLF32-500)

Berat beban maks.: $15 \mathrm{~kg} \approx 147 \mathrm{~N}$

Maka perhitungannya sebagai berikut :

$$
\begin{aligned}
& F=p \cdot \pi \cdot\left(D^{2}-d^{2}\right) / 4 \\
& F=4 \cdot 3,14 \cdot\left(50^{2}-32^{2}\right) / 4 \\
& F=464[N]
\end{aligned}
$$

Pada proses dorong, material velg juga mengalami gesekan dengan frame pendorong yang terbuat dari besi. Maka, juga perlu dilakukan analisa gaya gesek statisnya.

$$
\begin{aligned}
& F_{g}=\mu s . N \\
& F_{g}=0,74.464 N \\
& F_{g}=343,36[N]
\end{aligned}
$$

Dari kalkulasi didapatkan kesimpulan bahwa pneumatik yang digunakan mampu mendorong beban, karena gaya dorong normalnya masih lebih besar daripada gaya geseknya.

\section{Perencanaan Kapasitas Udara}

Setelah mengetahui spesifikasi silinder pneumatik yang digunakan dalam sistem, langkah selanjutnya adalah merancang kebutuhan penggunaan udara yang digunakan dalam sistem. Perancangan penggunaan kapasitas udara ini bertujuan untuk mengetahui kapasitas yang dibutuhkan sistem dalam kurun waktu tertentu. Dalam perhitungan ini, waktu yang ditentukan adalah dalam satu hari produksi. Dengan jumlah rata-rata produksi dalam satu hari adalah 4000 buah velg untuk satu lini produksi. Untuk perhitungannya juga dibedakan sesuai dengan fungsinya karena setiap fungsi pneumatik memiliki spesifikasi yang berbeda.

\section{Pneumatik Penahan}

Pneumatik yang digunakan adalah dengan spesifikasi sebagai berikut:

Diameter rod : $16 \mathrm{~mm}$

Diameter silinder : $40 \mathrm{~mm}$

Panjang langkah : $75 \mathrm{~mm}$

Tipe pneumatik : Double acting (SMC CA2D40-75)

Jumlah unit $\quad: 2$ unit

Perhitungan kapasitas udara yang diperlukan adalah sebagai berikut :

$$
\begin{aligned}
& Q=\left\{\left(\frac{\pi}{4} D^{2} \cdot h\right)+\left(\frac{\pi}{4}(D-d)^{2} \cdot h\right)\right\} n \cdot p k \\
& Q=\left\{\left(\frac{\pi}{4} 4^{2} \cdot 7,5\right)+\left(\frac{\pi}{4}(4-1,6)^{2} \cdot 7,5\right)\right\} 4000 \cdot 4,95 \\
& Q=2537904,209\left[\mathrm{~cm}^{3}\right] \\
& Q \approx 2,537[\mathrm{kl}] / \text { unit }
\end{aligned}
$$

Pada jenis ini memiliki dua unit, maka total konsumsi udara adalah 5,074 [kl].

\section{Pneumatik Pengangkat}

Pneumatik yang digunakan adalah dengan spesifikasi sebagai berikut:

Diameter rod : $16 \mathrm{~mm}$ 
Diameter silinder : 40mm

Panjang langkah : 50mm

Tipe pneumatik : Double acting (SMC CA2G40-50)

Jumlah unit $\quad: 1$ unit

Perhitungan kapasitas udara yang diperlukan adalah sebagai berikut :

$Q=\left\{\left(\frac{\pi}{4} D^{2} \cdot h\right)+\left(\frac{\pi}{4}(D-d)^{2} \cdot h\right)\right\} n \cdot p k$

$Q=\left\{\left(\frac{\pi}{4} 4^{2} \cdot 5\right)+\left(\frac{\pi}{4}(4-1,6)^{2} \cdot 5\right)\right\} 4000.4,95$

$Q=1691936,14\left[\mathrm{~cm}^{3}\right]$

$Q \approx 1,691[\mathrm{kl}] /$ unit

Pada jenis ini hanya memiliki satu unit, maka total konsumsi udara adalah 1,691 [kl].

\section{Pneumatik Pendorong}

Pneumatik yang digunakan adalah dengan spesifikasi sebagai berikut:

Diameter rod : $32 \mathrm{~mm}$

Diameter silinder : $50 \mathrm{~mm}$

Panjang langkah : 500mm

Tipe pneumatik : Double acting (MEDAN PLF32-500)

Jumlah unit $\quad: 1$ unit

Perhitungan kapasitas udara yang diperlukan adalah sebagai berikut :

$Q=\left\{\left(\frac{\pi}{4} D^{2} \cdot h\right)+\left(\frac{\pi}{4}(D-d)^{2} \cdot h\right)\right\} n \cdot p k$

$Q=\left\{\left(\frac{\pi}{4} 5^{2} \cdot 50\right)+\left(\frac{\pi}{4}(5-3,2)^{2} \cdot 50\right)\right\} 4000.4,95$

$Q=21957847,69\left[\mathrm{~cm}^{3}\right]$

$Q \approx 21,957[\mathrm{kl}] /$ unit

Pada jenis ini hanya memiliki satu unit, maka total konsumsi udara adalah 21,957 [kl].

Maka, total kebutuhan konsumsi udara selama satu hari produksi dengan jumlah produksi per hari adalah 4000 unit velg dibutuhkan volume udara sebanyak 28,722 [kl].

\section{Proses Fabrikasi dan Instalasi}

Proses fabrikasi dilakukan setelah kalkulasi baik untuk kebutuhan material dan kalkulasi teknik selesai dilakukan. Dalam pembuatan Mesin Feeder Otomatis ini, terdapat tiga proses utama yang saling melengkapi.

\section{Fabrikasi Komponen Mekanik}

Dalam proses fabrikasi komponen mekanik, terdapat dua komponen utama yang dipisahkan dari bagian mekanik. Yaitu bagian rangka dan swing system. Pada bagian rangka, merupakan bagian yang terdiri dari susunan besi profil sebagai penahan komponen lainnya dalam sistem Mesin Feeder Otomatis. Sedangkan untuk swing system, merupakan bagian yang terpisah dari rangka utama dan ditempelkan dengan pengelasan pada rangka konveyor yang sudah ada pada lini produksi. Swing system ini, berfungsi sebagai penahan laju material velg yang akan masuk ke rangka utama dari Mesin Feeder Otomatis, sehingga prosesnya dapat berjalan teratur.

\section{Instalasi Komponen Pneumatik}

Proses instalasi komponen pneumatik dilakukan setelah rangka utama dan swing system selesai dibuat. Hal ini dikarenakan komponen pneumatik merupakan komponen yang menempel pada komponen mekanik yang dibuat.Dengan selesainya pemasangan rangkaian komponen pneumatik, dapat dilanjutkan dengan instalasi komponen elektrikalnya.

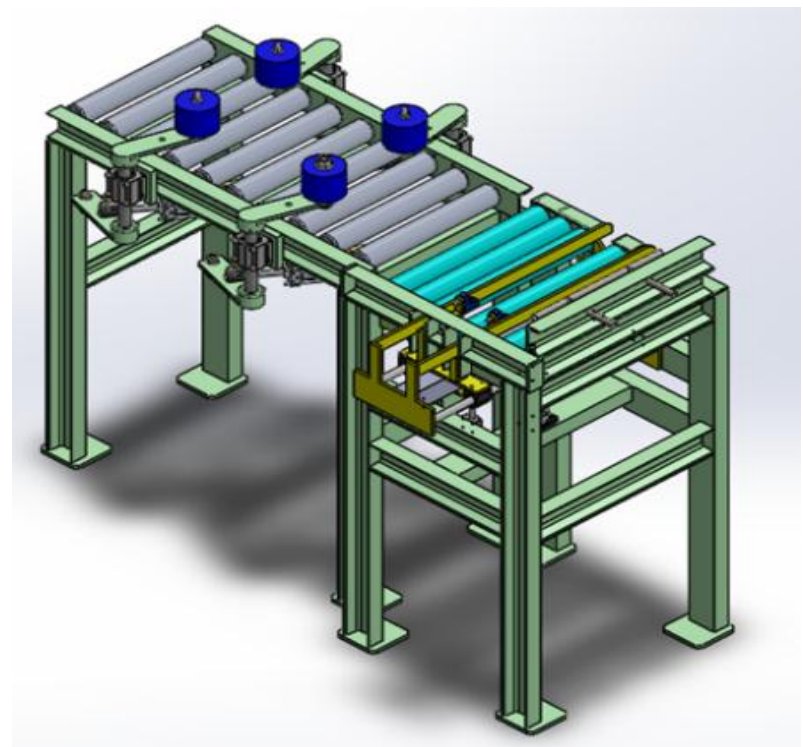

Gambar 6.Mesin Feeder Otomatis

\section{Instalasi Komponen Elektrik}

Proses instalasi komponen elektrik dalam tahap fabrikasi Mesin Feeder Otomatis ini merupakan tahap akhir dari seluruh tahapan dalam fabrikasi.Setelah tahap akhir fabrikasi selesai, dan semua komponen baik dari komponen mekanik, komponen pneumatik, dan komponen elektrik selesai dirangkai maka proses fabrikasi untuk Mesin Feeder otomatis dinyatakan selesai.

\section{Rangkaian Kerja Sistem}

Setelah semua komponen telah terinstalasi sesuai dengan fungsi dan 
bagiannya, maka tahapan selanjutnya adalah dilakukan pengujian operasi untuk mengetahui hasil rangkaian kerja sistem secara keseluruhan. Hal ini perlu dilakukan agar terjadi kesesuaian antar komponen mekanik, elektrik, dan pneumatik. Rangkaian kerja sistem untuk Feeder dijelaskan sebagai berikut :

1. Material velg meluncur turun dari gravity roll conveyor yang berasal dari Welding Station akibat adanya perbedaan ketinggian, dan menuju area feeder.

2. Material velg yang menuju area feeder dideteksi oleh photosensor, yang akan mengirimkan sinyal ke pneumatik penahan sehingga velg dapat ditahan atau dilanjutkan ke meja feeder jika tidak ada material tersisa di meja Feeder. Velg ditahan dengan bantalan penjepit jika pada satu proses terdapat jumlah material velg lebih dari dua buah.

3. Material velg yang berada di meja velg dideteksi oleh photosensor kembali, guna mengindentifikasi bahwa terdapat velg yang siap untuk proses selanjutnya.

4. Material velg di atas meja feeder akan diangkat sehingga ketinggiannya di atas roll conveyor. Velg terangkat karena adanya pneumatik pengangkat di bawah meja feeder. Kemudian velg di dorong menuju Mesin Run-Out dengan menggunakan pneumatik pendorong. Di Mesin Run-Out dilakukan pengukuran kebulatan velg sebagai perangkat uji kualitas.

5. Saat velg sudah masuk kedalam MesinRun-Out, photosensor tidak mendeteksi material, sehingga memberikan sinyal ke pneumatik pengangkat dan pendorong untuk kembali ke posisi semula dan siap menerima material velg yang datang dari conveyor.

6. Proses pengukuran di Mesin Run-Out membutuhkan waktu sekitar 9 detik. Saat velg selesai diukur, end stroke dari Mesin Run-Out akan menyentuh limit switch yang dipasang sebagai rangkaian dari sistem Feeder. Limit Switch ini memberikan sinyal bahwa material velg siap dimasukkan kembali ke Mesin RunOut.

\section{Panduan Perawatan}

Bagian-bagian Mesin Feeder Otomatis ini perlu dilakukan perawatan bertujuan agar komponennya dapat bekerja dengan baik sehingga memperpanjang umur mesin. Karena penggunaannya yang otomatis, sehingga perawatan yang dilakukan adalah perawatan yang dilakukan sesuai jadwal.

\section{Hasil Uji Validasi}

Pengujian mesin feeder Otomatis dilakukan dengan metode pencatatan waktu kerja mesin selama satu siklus. Satu siklus pencatatan untuk kerja mesin diawali dari material datang menuju stopper kemudian menuju proses pengangkatan, dan diakhiri setelah material velg masuk ke area Mesin Run-Out. Untuk pengujiannya, menggunakan sampel material velg dengan berbagai ukuran dan dilakukan pencatatan sebanyak lima kali proses.

Tabel 9. Hasil Pengujian Mesin Feeder Otomatis

\begin{tabular}{|c|c|c|c|c|c|c|c|c|c|c|}
\hline \multirow[b]{2}{*}{$\begin{array}{c}\text { Jumbah } \\
\text { Percobaan }\end{array}$} & \multicolumn{10}{|c|}{ Jenis Velg } \\
\hline & \multicolumn{2}{|c|}{$\begin{array}{c}\text { Y-89 } \\
\text { (Hand Tractor Quick) } \\
12 \text { inch } 5.6 \mathrm{~kg}\end{array}$} & \multicolumn{2}{|c|}{$\begin{array}{c}\text { HT-KHS } \\
\text { (Hand Tractor Quick) } \\
13 \text { inch } 6.6 \mathrm{~kg} \\
\end{array}$} & \multicolumn{2}{|c|}{$\begin{array}{c}\text { D38Al } \\
\text { (Daihatsu Xenia 14") } \\
14 \mathrm{inch} / 7.75 \mathrm{~kg}\end{array}$} & \multicolumn{2}{|c|}{$\begin{array}{c}\text { GMI } 700 \\
\text { (General Motors) } \\
15 \text { inch/12,17 kg }\end{array}$} & \multicolumn{2}{|c|}{$\begin{array}{c}\text { AVANTEK } \\
\text { (Aftemarket) } \\
15 \mathrm{inch} / 4.1 \mathrm{~kg}\end{array}$} \\
\hline 1 & 2,6 & detik & 2,6 & detik & 2,7 & detik & 3,4 & detik & 3,2 & detik \\
\hline 2 & 2,6 & detik & 2,6 & detik & 2,8 & detik & 3,4 & detik & 3,4 & detik \\
\hline 3 & 2,5 & detik & 2,7 & detik & 2,9 & detik & 3,5 & detik & 3,4 & detik \\
\hline 4 & 2,5 & detik & 2,6 & detik & 2,8 & detik & 3,2 & detik & 3,6 & detik \\
\hline 5 & 2,7 & detik & 2,5 & detik & 2,8 & detik & 3,2 & detik & 3,4 & detik \\
\hline 6 & 2,6 & detik & 2,7 & detik & 2,9 & detik & 3,3 & detik & 3,6 & detik \\
\hline 7 & 2,7 & detik & 2,7 & detik & 2,8 & detik & 3,3 & detik & 3,6 & detik \\
\hline 8 & 2,5 & detik & 2,8 & detik & 2,9 & detik & 3,3 & detik & 3,7 & detik \\
\hline 9 & 2,6 & detik & 2,6 & detik & 2,9 & detik & 3,5 & detik & 3,5 & detik \\
\hline 10 & 2,6 & detik & 2,6 & detik & 2,8 & detik & 3,3 & detik & 3,6 & detik \\
\hline
\end{tabular}

Berdasarkan hasil pengujian yang sudah dilakukan, didapatkan hasil proses transfer material dengan menggunakan Mesin Feeder Otomatis paling lama ditempuh dalam waktu 3,7 detik untuk jenis velg dengan ukuran dan bobot terbesar yaitu jenis AVANTEK. Dan jika dibandingkan dengan waktu siklus kerja Mesin Run-Out yang memiliki waktu kerja rata-rata selama 9,6 detik. Sehingga dapat disimpulkan bahwa waktu kerja Mesin Feeder Otomatis tidak mengganggu atau mempengaruhi waktu kerja Mesin Run-Out, dan proses dapat berlangsung secara terus menerus tanpa ada waktu menunggu material velg datang.

\section{Efisiensi Produksi}

Penerapan sistem otomasi pada proses transfer material menuju Mesin Run-Out memberikan perubahan pada proses produksi yang berlangsung. Perbandingan dilakukan 
dengan pengambilan data produksi bulanan selama tiga bulan setelah Feeder Otomatis digunakan secara normal. Data Produksi Manual dan Otomasi diambil pada dua buah jalur produksi yang berbeda, dimana untuk penerapan otomasi baru diterapkan untuk satu jalur dahulu untuk mengetahui efektifitasnya. Perbedaan antara sistem manual dengan tenaga manusia dengan sistem otomasi ditampilkan dalam tabel 4.6 berikut:

Tabel 10 Efisiensi Jumlah Produksi

\begin{tabular}{|l|c|c|c|c|}
\hline \multicolumn{1}{|c|}{ Bulan } & $\begin{array}{c}\text { Realisasi } \\
\text { Produksi Manual } \\
\text { (buah) }\end{array}$ & $\begin{array}{c}\text { Realisasi } \\
\text { Produksi Otomasi } \\
\text { (buah) }\end{array}$ & $\begin{array}{c}\text { Selisih } \\
\text { (buah) }\end{array}$ & $\begin{array}{c}\text { Efisiensi } \\
\text { (\%) }\end{array}$ \\
\hline Desember 2012 & 88225 & 90821 & 2596 & 2,94 \\
\hline Januari 2013 & 90013 & 92855 & 2842 & 3,16 \\
\hline Februari 2013 & 92413 & 95226 & 2813 & 3,04 \\
\hline
\end{tabular}

Dari perbandingan jumlah produksi diatas, didapatkan hasil bahwa untuk parameter jumlah produksi, dengan penerapan sistem otomasi mampu menghasilkan output produksi yang lebih baik dengan rata-rata 3\% tiap bulannya.

Selain jumlah produksi yang dapat ditingkatkan, dengan penerapan otomasi juga memberikan keuntungan lainnya, seperti efisiensi jumlah tenaga manusia, tidak adanya kecelakaan kerja, dan kualitas velg yang terjaga.

\section{KESIMPULAN}

Berdasarkan hasil rancangan Mesin Feeder Otomatis yang diterapkan pada proses produksi di lini assembly PT. X, maka dapat ditarik kesimpulan berdasarkan pada tujuan perancangan Mesin Feeder Otomatis adalah sebagai berikut :

1. Proses Feeder yang awalnya dioperasikan secara manual, telah diubah secara sistem menjadi otomasi dengan menggunakan perangkat mekanik, elektrikal, dan pneumatik. Sehingga proses produksi dapat berlangsung secara terus menerus tanpa ada waktu yang terbuang.

2. Pengujian hasil rancangan Mesin Feeder Otomatis dilakukan dengan menggunakan velg dalam berbagai ukuran untuk mengetahui waktu kerja efektif dari Mesin Feeder Otomatis, dan didapatkan hasil waktu kerja selama 3,6 detik. Yang artinya tidak melampaui waktu kerja Mesin RunOut, sehingga proses transfer material dapat berlangsung secara konstan dan produktivitas dapat tercapai maksimal.

3. Dengan anggaran yang dikeluarkan sebagai investasi pembuatan Mesin Feeder Otomatis, menghasilkan proses produksi yang optimal secara otomasi penuh dan dapat menghasilkan efisiensi tenaga manusia sebanyak tiga orang yang dapat dialokasikan ke proses lain.

4. Dengan penerapan Mesin Feeder Otomatis pada proses feeder di lini assembly, mampu menghilangkan potensi bahaya berupa operator terjepit material, hilangnya waktu menunggu saat operator tidak ada ditempat, dan kualitas velg yang tetap terjaga. Hal ini sebagai dampak dari penerapan sistem otomasi pada proses transfer material di Mesin Feeder Otomatis.

\section{DAFTAR PUSTAKA}

Beitz, Wolfgang., dan Gerhard Pahl. (2007). Engineering Design. London : The Design Council.

Budynass., dan Nisbett. (2006). Shigley's Mechanical Engineering Design,Eighth Edition. New York : McGraw-Hill Primis.

J., Jansch., dan Birkhofer H, May 2006, “The Development of The Guideline VDI 2221 - The Change of Direction", International Design Conference Design 2006 - Page 45-52, https://www.designsociety.org/downloa d-

publication/18983/the_development_of _the_guideline_vdi_2221-

the_change_of_direction, 29 Desember 2014.

Jutz, Herman., dan Eduard Scharkus. (1979). Westermann Tables. New Delhi : Wiley Eastern Limited.

Khurmi, R.S., dan J.K. Gupta. (2005). A Textbook Of Machine Design. New Delhi : Eurasia Publishing House (Pvt.) Ltd.

Newnan, G. Donald., Ted G. Eschenbach., dan Jerome P. Lavelle. (2004). Engineering Economic Analysis, Ninth Edition. New York : Oxford University Press. 
Nof, Shimon Y. (2009). Springer Handbook of Automation. New York : Springer Science \& Business Media.

Sandler, Ben-Zion. (1999). Robotics : Designing Mechanisms for Automated Machinery. San Diego : Academic Press.

Shigley, Joseph E., dan Charles R. Mischke. (1996). Standard Handbook of Machine Design. New York : The McGraw-Hill Companies, Inc. 